\title{
Influences of land use/cover on water quality in the upper and middle reaches of River Njoro, Kenya
}

\author{
William A. Shivoga,, ${ }^{1}$ Mucai Muchiri, ${ }^{2}$ Samuel Kibichi, ${ }^{2}$ Jethro Odanga, ${ }^{3}$ Scott N. Miller, ${ }^{4}$ \\ Tracy J. Baldyga, ${ }^{4}$ Eric M. Enanga ${ }^{1}$ and Maina C. Gichaba ${ }^{5}$ \\ ${ }^{1}$ Department of Environmental Science, Egerton University, PO Box 536, Njoro, Kenya, ${ }^{2}$ Department of Fisheries, \\ Moi University, PO Box 3900, Eldoret, Kenya, ${ }^{3}$ Department of Wildlife Management, Moi University, PO Box 3900, Eldoret, \\ Kenya, ${ }^{4}$ Department of Renewable Resources, University of Wyoming, Box 3354, Wyoming, USA, ${ }^{5}$ Department of Geography, \\ Egerton University, PO Box 536, Njoro, Kenya
}

\begin{abstract}
Data from 10 sampling sites along the River Njoro are used to examine the contribution of nutrients from upstream land uses draining each of the sampling sites. The data also are used to assess whether both the proportion of land uses and the size of the subwatersheds account for the variability in water quality in the River Njoro watershed. Geographical Information System analysis was used to determine the spatial distribution of land-cover types and subwatersheds contributing run-off to the sampling sites in the River Njoro. Standard Digital Elevation Model-based routines were used to establish the watershed area contributing run-off to each sampling site. Water and sediment samples were collected for chemical analysis, and the nutrient levels were related to the upstream land-use types and the size of the subwatersheds. The mid-stream portion of the River Njoro (near Egerton University) accounts for the highest nutrient contributions. The percentage contribution is magnified by additions from industrial, human settlements and agricultural land uses around the University. There is a significant decrease in nutrient levels downstream, however, indicating natural purification as the river flows through an area of large-scale farming with intense, well-preserved riparian and in-stream vegetation. Steep slopes of the land upstream of Egerton University enhance erosion and nutrient losses from those subwatersheds. Mixed small-scale agricultural and bare lands contribute over $55 \%$ of the phosphorus load to the upper and mid-reaches of the River Njoro. The size of the subwatershed accounts for about $53 \%$ of the variability in the soluble phosphorus in the river. The land-use subwatershed proportions are important for characterizing and modelling water quality in the River Njoro watershed. Upland land uses are as important as near-stream land uses. We suggest that conservation of intact riparian corridor along the river and its tributaries contributes significantly to natural purification processes and recovery of the ecological integrity of the River Njoro ecosystem.
\end{abstract}

\section{Key words}

ecological integrity, natural purification, nutrient levels, riparian zone, subwatersheds, upland land use, water quality.

\section{INTRODUCTION}

Human-induced disturbances resulting from land-use activities have the greatest potential for introducing enduring changes to the ecological structure and functions of watersheds. Over the years, numerous factors have contributed to the degradation of water resources within the

\footnotetext{
*Corresponding author. Email: shivogawa@yahoo.co.uk or shivoga@sumawa.or.ke

Accepted for publication 20 April 2007.
}

River Njoro watershed. A high population growth rate and associated land-use changes have placed high demands on the watershed resources, thereby upsetting its environmental stability (Karanja et al. 1986), and this situation has impacted negatively on the ecological integrity and hydrological processes in the River Njoro watershed (Chemilil 1995; Bretschko 1995; Mathooko 2001; Shivoga 2001).

The sprawl patterns of human settlements and land-use changes have been implicated as the primary causes of the deteriorating health of the River Njoro watershed. Little is known, however, about the quantitative influences of specific 
land-use patterns on the water quality of River Njoro. Landcover classification, using Landsat images (Baldyga $e t$ al. 2004 ), indicates a loss of about $20 \%$ of both indigenous and plantation forests between 1986 and 2003 in the upper River Njoro watershed. There also was a $6 \%$ reduction in areas of large-scale farms. The conversion of forested and large-scale farm areas has been accompanied by increase in small-scale mixed agriculture and human settlements.

River Njoro is the main freshwater source to Lake Nakuru, a shallow, hyper-eutrophic, alkaline-saline endorheic lake in the Eastern Rift Valley of Kenya. The lake is a Ramsar site, being famous for its spectacular bird life, particularly the lesser flamingos (Phoeniconaias minor), greater flamingos (Phoenicopterus ruber), and great white pelicans (Pelecanus onocrotalus roseus). As a simplified, discrete and productive ecosystem, Lake Nakuru is very suitable for ecosystem research in the region.

This paper discusses the relationship between the upstream proportion of land-use types and riparian buffer zones to nutrient concentrations and supply to downstream reaches of the river. It also discusses the relationship between the proportion of land uses and the size of delineated subwatersheds (an area of land draining to a specific sampling site in the river) and the water quality in the upper and mid-streams of the River Njoro watershed. The findings indicate that near-stream riparian zones reduce nutrients and sediment influxes into the River Njoro channel, providing a natural purification and recovery of the ecological integrity of the downstream river ecosystem. It is concluded therefore that land use near the stream accounts for the variability in water quality more than land use in the entire River Njoro watershed.

\section{METHODS Study area}

The River Njoro watershed (Fig. 1) covers an area of $280 \mathrm{~km}^{2}$ (SUMAWA 2004). It is located in the Rift Valley Province of Kenya at $0^{\circ} 30^{\prime} \mathrm{S}, 35^{\circ} 20^{\prime} \mathrm{E}$. The river originates in the Eastern Escarpment of the Mau Forest Complex one of the five major water sources in Kenya. The River Njoro is about $50 \mathrm{~km}$ in length, with its source being $\approx 3000 \mathrm{~m}$ a.s.l., and the mouth at Lake Nakuru at $1759 \mathrm{~m}$ a.s.l. The river drains forested and highly populated agricultural lands before flowing through the towns of Njoro and Nakuru. The lake is enclosed within the Lake Nakuru National Park, which is famous around the world for its large populations of flamingos. The River Njoro is structured

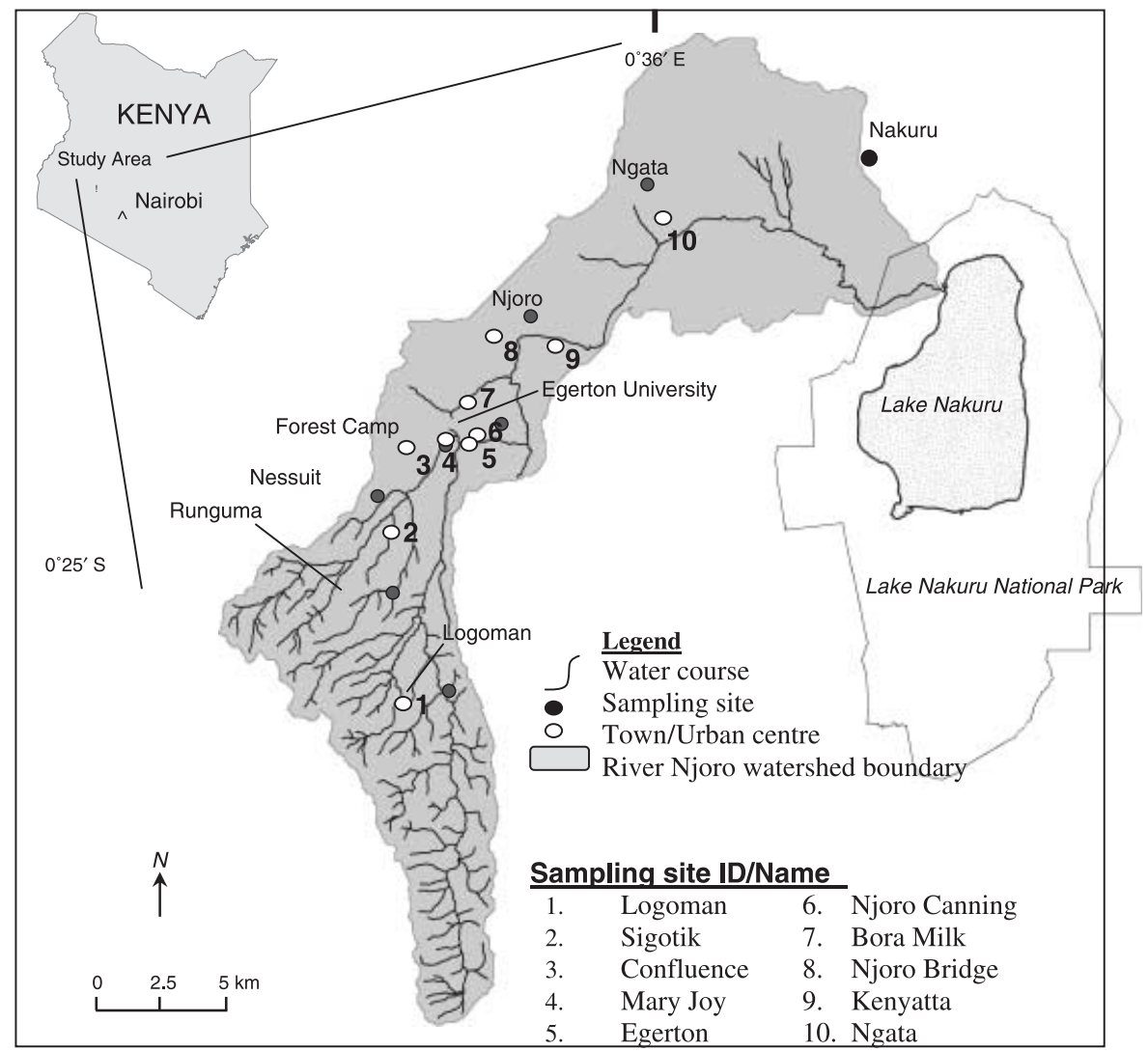

Fig. 1. River Njoro watershed and sampling sites, Kenya. 
in a typical riffle-pool sequence, with soft substratum and bedrock in the pool and riffle sections, respectively. The soils in the river's watershed are predominantly ultisols and entisols. The soil textures range from clay loams in the lower portion of the study area, to sandy clay loams in the plantation and indigenous forest areas at higher elevations. The mean annual rainfall of the area from 1949 to 2001, as measured at the Kenya Agricultural Research InstituteNjoro, is $939.3 \mathrm{~mm}$. The rainfall is tri-modally distributed, with peaks in April, August and November. The average annual minimum and maximum temperatures in the area are $9^{\circ} \mathrm{C}$ and $24^{\circ} \mathrm{C}$, respectively.

The profile of the landscape elevation gradient of the sampling sites is shown in Figure 2. Based on their altitude, the sampling sites are categorized into three groups: (i) an upstream zone (Logoman, Sigotik and Confluence sites); (ii) a midstream zone (Mary Joy, Egerton University, Njoro Canning, Bora Milk Plant, Njoro Bridge and Kenyatta); and (iii) Ngata in the downstream end of the river. The upstream sites are characterized with a steep slope typical of stream headwaters, and the midstream has a gentle gradient, while the downstream is within the river lowlands.

\section{Methods}

Ten sampling sites were selected to represent combinations of natural and human factors that collectively can influence the physical, chemical and biological characteristics of the water quality in the upper and mid-reaches of the River Njoro watershed. The sampling sites for water quality assessment were established along the river on the basis of land uses in the upper and mid-stretches of the watershed. Routine monthly sampling was carried out at each sampling site to collect water samples for chemical analysis of nutrients (phosphorus, nitrogen and carbon).

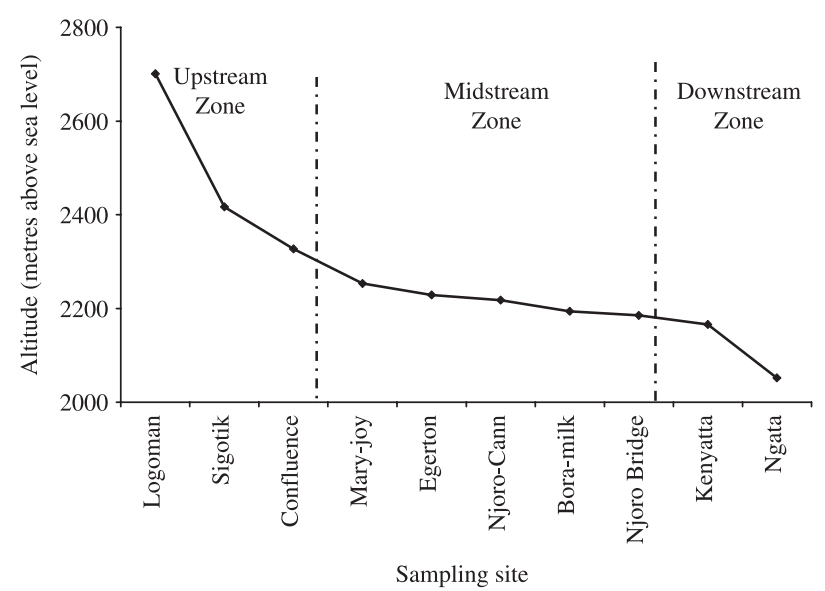

Fig. 2. Landscape profile of sampling sites in upstream and midstream zones relative to altitude above sea level.
These chemical analyses were carried out according to the standard procedures outlined by APHA (1992).

Three Landsat TM and one Landsat TM + scenes were selected for this study. Table 1 lists sensors and acquisition dates for these four images. The selected images correspond by year with census dates, for eventual correlation between land-cover changes and human migration and population increases. Topographical contour maps (Government of Kenya 1974) were acquired and digitized to create a 50-m Digital Elevation Model using ARCINFo. This resolution allows Automated Geospatial Watershed Assessment (AGWA), to produce a suitable delineation of the watershed and subwatersheds for each sampling site. The subwatersheds represent the areas of land draining to each of the sampling sites in the river.

To detect land-use changes between 1986 and 2003, six land-use classes (mixed small-scale agriculture; large-scale agriculture; plantation forest; indigenous forest; grassland; and bare ground) were identified and used in this study. An unsupervised classification, using the Iterative SelfOrganizing data Analysis Technique, was performed on the Landsat imageries, separating out 50 spectral clusters. Data clusters were then assigned to one of the six land-use classes. ArcView extension of AGWA Tool (version 1.32) was used to 'delineate' the 10 subwatersheds, based on natural topographical features to define the watershed boundary for each sampling site. The sampling sites were used to delineate the subwatersheds, with each subwatershed containing a single hydrological outlet (sometimes called a 'pour point'). The value of using this unconventional view of the landscape is that the cumulative effects of landscape condition on water quality can be assessed, thereby increasing the predictive power of any determined relationships between land cover and water quality parameters (Lopez \& Nash 2006).

\section{RESULTS AND DISCUSSION Land cover}

Figure 3 illustrates the size and proportions of different land-cover types in the upper and mid-reaches of the River Njoro watershed that contribute run-off to sampling sites.

Table 1. Satellite data used in River Njoro study

\begin{tabular}{lll}
\hline Image date & Sensor & Resolution \\
\hline January 1986 & Landsat TM & $30 \mathrm{~m}$ \\
March 1989 & Landsat TM & $30 \mathrm{~m}$ \\
January 2000 & Landsat TM & $30 \mathrm{~m}$ \\
February 2003 & Landsat TM + & $30 \mathrm{~m}$ \\
\hline
\end{tabular}


As noted above, the study area is characterized by six landcover classes, including (i) indigenous forest; (ii) plantation forest; (iii) grassland; (iv) large-scale agriculture; (v) mixed small-scale agriculture; and (vi) bare land. There is a significant increase in the percentage of the area covered by mixed small-scale agriculture and bare land downstream from the uppermost sampled site (Logoman) to the lower sites around Egerton University. In contrast, there is an overall decrease in the downstream land-cover area of grasslands, large-scale agriculture, and indigenous forest from the uppermost site of the watershed.

The changes in land-cover change within River Njoro watershed from 1986 to 2003 are presented in Figure 4, while the overall changes in land cover between 1986 and 2003 are shown in Table 2. There is an overall increase of $26 \%$ in mixed small-scale agriculture and grassland in the upper and mid-reaches of the River Njoro watershed between 1986 and 2003. This corresponds to a similar percentage decrease in large-scale agriculture, plantation and indigenous forest during the same period. It is evident that large-scale farms and forested lands are being converted to mixed small-scale farms and human settlement in the watershed. The trend in forest loss is analogous to historical changes in the Mau Forest Complex. The larger Mau Forest Complex has undergone significant losses throughout its extent (Kenya Forest Working Group 2001). The main conservation problem facing Mau is similar to that facing many Kenyan forests; namely, increasing pressures on productive land from an expanding population. Baldyga et al. (2004) reported rapid plantation forest losses between 2000 and 2003 in the uppermost regions of the watershed. By 2003, the majority of plantation forests were converted to small-scale agriculture, accompanied with a large net loss in large-scale agricultural systems (Fig. 3).

The increased area covered by mixed small-scale agriculture could be the result of increased human population in the area, and the extension of tillable land towards the forest reserves and the stream edge by
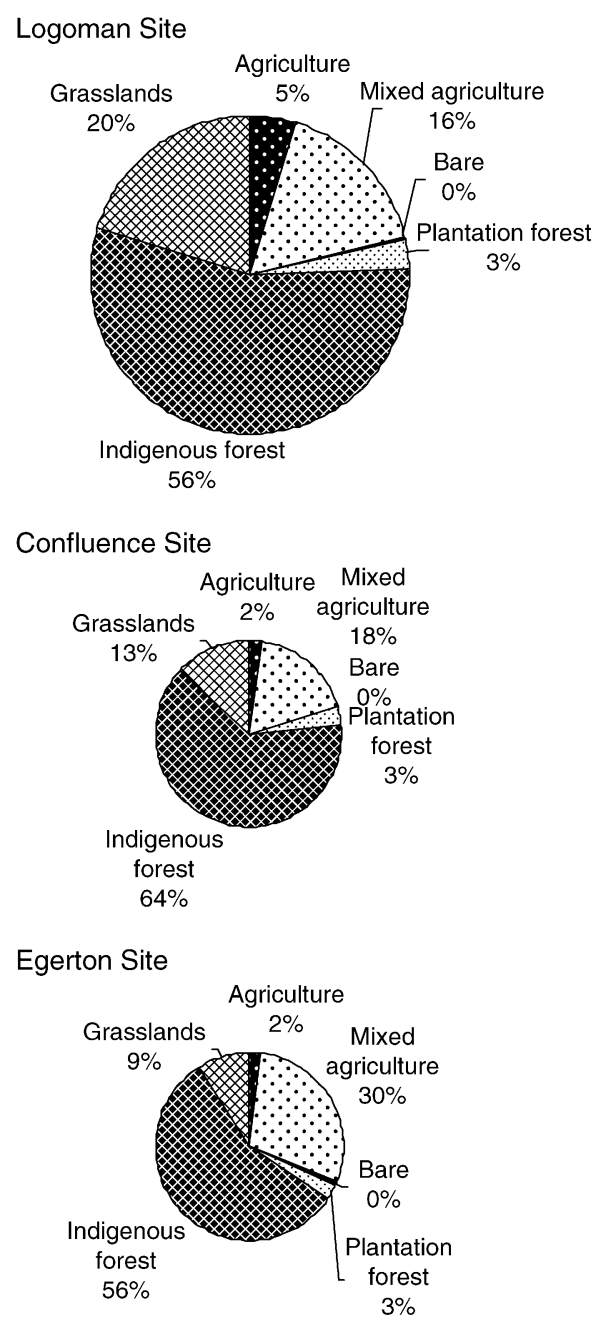

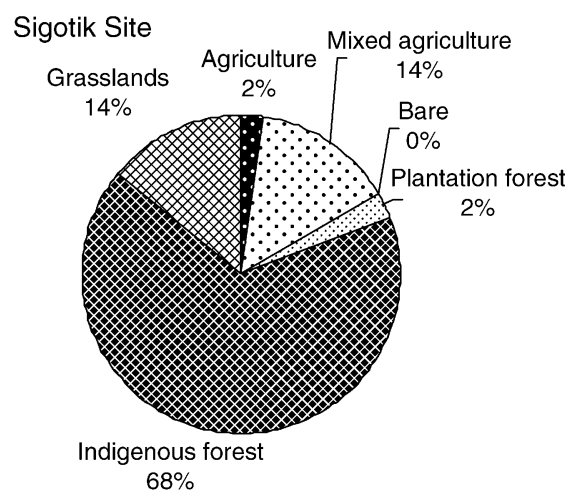

May Joy Site
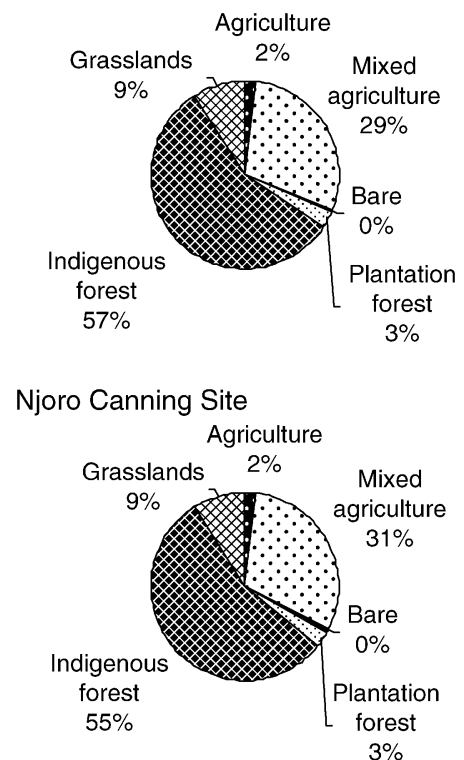

Fig. 3. Proportion of land uses for River Njoro watershed sampling sites. 
small-holder farmers. Over the years, land under forest (plantation and indigenous) and large-scale farms have been converted to mixed small-scale agriculture and settlements in the River Njoro watershed, resulting in hydrological changes in terms of annual run-off in the watershed (Table 3). There is an increased run-off volume during the rainy season, and a decreased run-off during the dry season. The middle and lowland stretches of the River Njoro are intermittent, flowing only sporadically following heavy rainfall events (Shivoga 2001). The flow regimes range from spates or peak flows during the rainy season, through to zero flow when the river effectively becomes a series of stagnant pools. This is followed by dryness when the surface water disappears completely, with the channel becoming dried out and sun-baked during the dry season. We hypothesize that this is the result of land-cover changes in the River Njoro watershed from the early 1990s, resulting in a loss of infiltration and water storage in the upper watershed, increased flashiness of the river with large water volumes flowing in a short duration, and downstream losses in water resources. Furthermore, the rapid increase in human population and associated agricultural and settlement activities in the early 1990s, have resulted in augmented water abstractions from the river, as well as massive inputs of sediments into the river (Mathooko 2001; Shivoga 2001). This has resulted in intensified water scarcity in the area, especially annually during the dry season (November to March).

\section{Spatial changes in nutrient levels}

There were significant differences in the concentration of phosphates, nitrates and organic matter (total organic carbon) (one-way ANova at $P<0.05$ ) among all the sampling sites in the River Njoro. Figure 5(a-c) illustrates the percentage contributions of nutrients from upstream land uses to downstream sampling sites during the study. The pattern

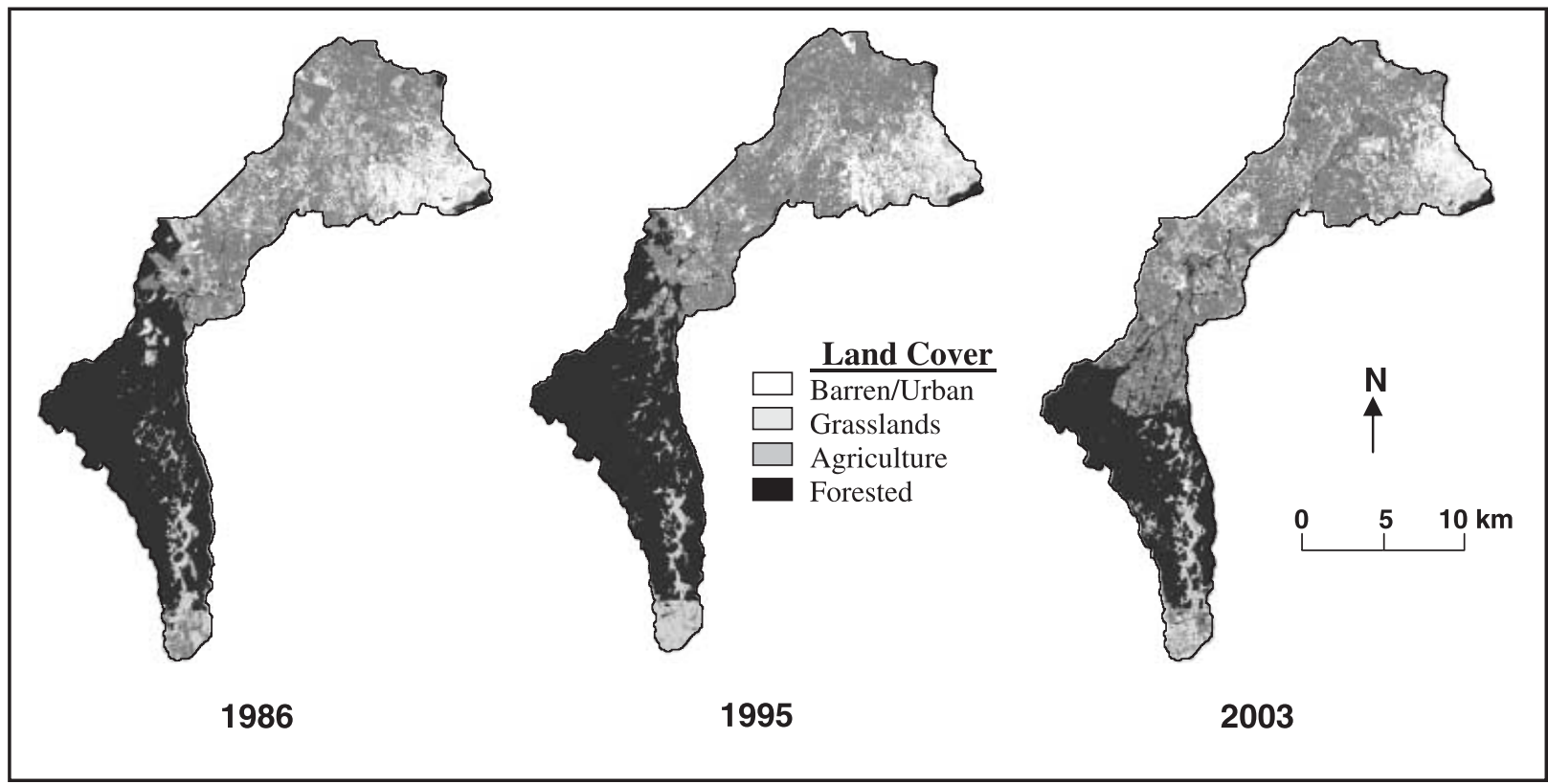

Fig. 4. Land-cover maps of the upper River Njoro watershed, illustrating greatest changes.

Table 2. Overall change in land cover in River Njoro watershed between 1986 and 2003

\begin{tabular}{|c|c|c|c|c|c|c|}
\hline \multirow[b]{2}{*}{ Land cover } & \multicolumn{2}{|c|}{1986} & \multicolumn{2}{|c|}{2003} & \multicolumn{2}{|c|}{ Change } \\
\hline & Area $\left(\mathrm{km}^{2}\right)$ & Total area (\%) & Area $\left(\mathrm{km}^{2}\right)$ & Total area (\%) & Area $\left(\mathrm{km}^{2}\right)$ & Total area (\%) \\
\hline Small-scale agriculture/Grassland & 94.2 & 26 & 187.66 & 53 & +93.46 & +26 \\
\hline Bare ground & 5.28 & 1 & 3.78 & 1 & -1.5 & 0 \\
\hline Plantation forest & 79.05 & 22 & 46.62 & 13 & -32.43 & -9 \\
\hline Indigenous forest & 122.12 & 34 & 85.73 & 24 & -36.39 & -10 \\
\hline Large-scale agriculture & 55.58 & 16 & 32.79 & 9 & -22.79 & -6 \\
\hline
\end{tabular}

(Source: Baldga et al. 2004). 
of percentage contribution of nitrates by stretches of land upstream of each site follows that illustrated by the phosphates. Spatially, the subwatersheds around Egerton University (i.e. between Mary Joy and Bora Milk) accounts for the highest percentage contribution of nutrients to the river. The pattern of percentage of nitrate contribution by

Table 3. Change in annual run-off in River Njoro watershed between 1986 and 2003

\begin{tabular}{lccc}
\hline Duration & $1986-1989$ & $1989-2000$ & $2000-2003$ \\
\hline Change in annual run-off & -0.85 & +31.34 & +108.11 \\
\hline
\end{tabular}

stretches of land upstream of each site also follows that illustrated by the phosphates. Spatially, the subwatersheds around Egerton University (i.e. between Mary Joy and Bora Milk) accounts for the highest percentage contribution of nutrients to the river. This is an expected finding because the major land-use activities around the University include human settlements, small-scale agriculture, education institutions, a vegetable canning factory, and a dairy plant, which probably constitute the major point and non-point phosphate and nitrate sources in the watershed. The main phosphate source in the surface waters is from the sewage treatment plant wastewater. The run-off draining the grazed grasslands, diffuse fertilized and manured crop fields, and wastewaters from the institutions and factories add

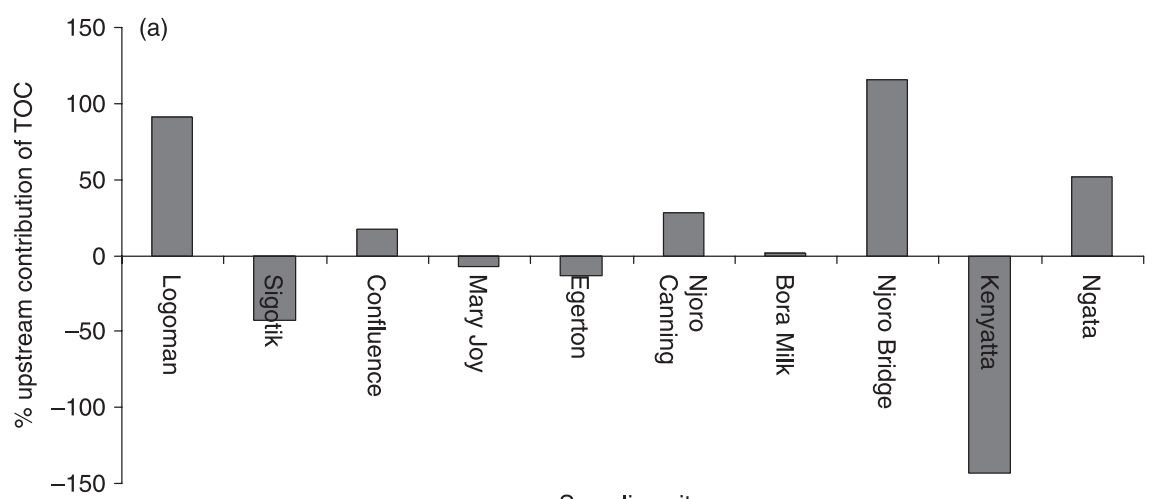

Sampling site

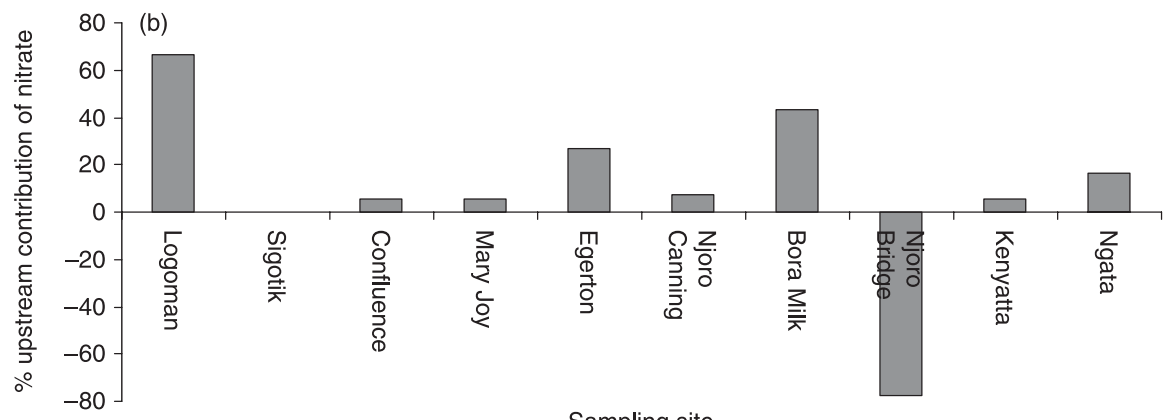

Sampling site

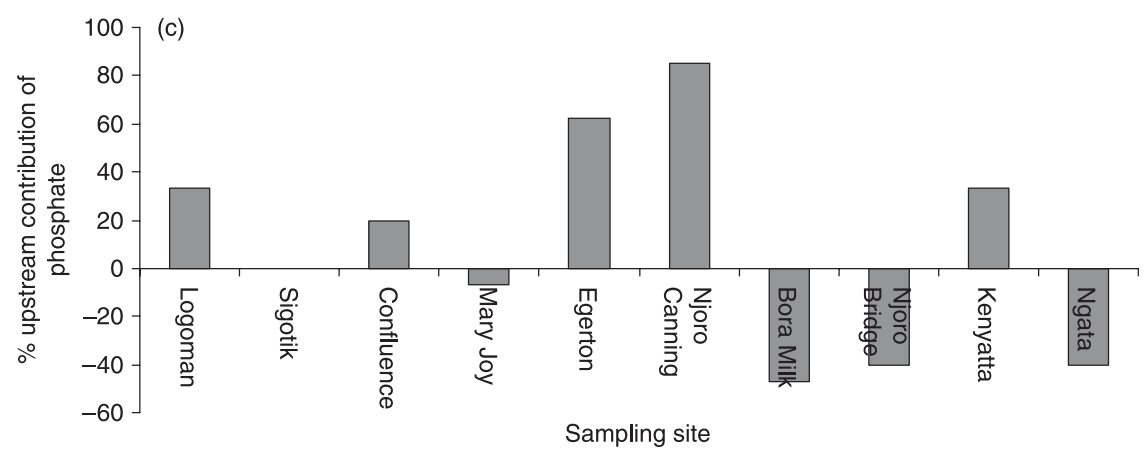

Fig. 5. (a-c) Downstream variations in percentage contributions of organic matter (total organic carbon - TOC) nitrate and phosphate by land stretch upstream of each sampling site (subwatershed) from the uppermost forested site to the downmost site at Ngata (negative percentage implies that upstream site has concentration greater than downstream site, indicating the actual trend is one of decrease). 
significantly to the nutrient load to the river. Detergents used for washing and cleaning in the river, homes, institutions and industries are a major phosphorus source to the river. The phosphorus enters the river through sewage inlets and non-point sources (e.g. washing sites along the river).

The steep slope of the land upstream and around Egerton University (Fig. 2) enhances erosion and nutrient losses from the subwatershed. Similar observations were reported by Tiessen (1995), who observed that greater slopes and a greater density of stream networks in a watershed increase erosion and phosphorus losses from the river's drainage.

The contribution of organic matter from land upstream of the Sigotik sampling site is low, compared to the concentrations recorded at the forested Logoman site (Fig. 5a). This situation is followed by an increased value from Sigotik to the Confluence. There is some relatively intact forest along the stream valley in this stretch of the river.

It is noted that low phosphate and nitrate levels were recoded at sampling sites in the stretch of the stream between Bora Milk and Njoro Bridge (Fig. 5b). This is likely a consequence of the undisturbed dense riparian forest and in-stream vegetation in this part of the River Njoro. The slope of the landscape in this stretch of the river is gentle, in contrast to the upstream fast-flowing reaches. Thus, this slow water flow allows for a longer interaction time between phosphorus loads reaching the stream, stream bed sediments and biota. The nutrient loss can occur as a result of adsorption to soil particles, and their subsequent sedimentation. Furthermore, this stretch is surrounded by large-scale farms that pump water from the river and boreholes, thereby reducing the need for frequent visits to the river by people and livestock. This facilitates the development of vegetation along the riparian

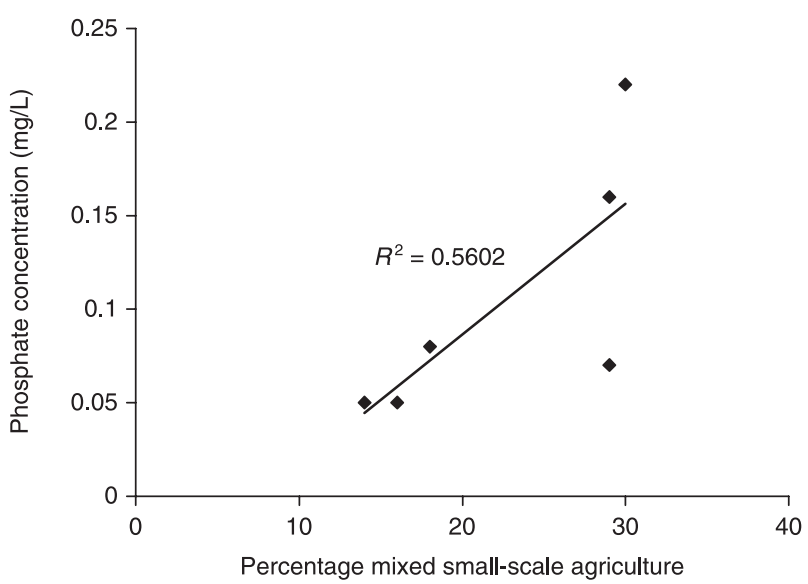

Fig. 6. Relationship between phosphate concentration and percentage proportion of land-cover areas of mixed small-scale agriculture. corridor, consisting of terrestrial and aquatic macrophyte plants (e.g. Potamageton sp. Typha latifoli, Phragmites australis, Cyperus papyrus). These plants are known to have a cleaning effect on nutrient-rich waters (e.g. Garcia-Cabellos et al. 2005; Harrington 2005). The plants are used in constructed wetlands for wastewater treatment. An intact riparian zone also can serve to retain nutrients from the large-scale farms surrounding the river, thereby significantly reducing the nutrient contributions from the arable land. Riparian forests adjacent to surface waters have been shown to reduce nutrients from agricultural run-off (Tiessen 1995).

There are significant positive relationships between the phosphorus loss and the proportion of land-cover area of mixed small-scale agriculture $\left(R^{2}=0.5602\right)$ in the River Njoro watershed (Fig. 6). This indicates that the major source of phosphorus contamination of stream water is from small-scale agricultural non-point sources. There is also a positive relationship $\left(R^{2}=0.5464\right)$ between the phosphorus loss and the proportion of land-cover area of bare land (Fig. 7). The mixed small-scale agriculture and bare land together contribute over $55 \%$ of the phosphorus load, on average, to the upper and mid-reaches of the River Njoro. In contrast, Figures 8-10 illustrate negative relationships, respectively, between the phosphorus loss and the percentage land-cover areas of large-scale agriculture $\left(R^{2}=0.2302\right)$, plantation forest $\left(R^{2}=0.0114\right)$ and indigenous forest $\left(R^{2}=0.2184\right)$. These findings demonstrate that the greater the percentage of large-scale agriculture, plantation forest, and indigenous forest land cover, the lower the phosphorus loss from the subwatershed. Similar observations were reported by Lopez and Nash (2006), who demonstrated that the percentage barren land enhances the total phosphorus in surface water and forest-related variables contribute equally, with a negative effect on the total phosphorus.

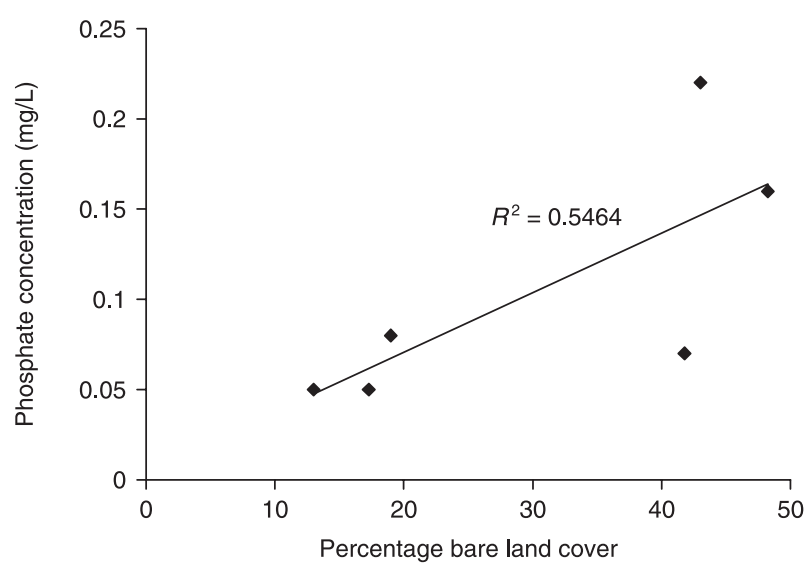

Fig. 7. Relationship between phosphate concentration and percentage proportion of land-cover areas of bare land. 
These study results indicate that the sizes of the subwatersheds account for about $53 \%$ of the variability in the soluble phosphorus in the River Njoro (Fig. 11), implying that the larger the size of the subwatershed, the greater the phosphorus contribution to the river water.

\section{CONCLUSIONS}

These study results generally support research findings on nutrient and sediment transport within small watersheds with forest or grass buffer areas, between disturbed uplands. Rivers serve both as integrators of landscape characteristics and as recipients of pollutants from the atmosphere and the landscape. The proportions of different land uses within a watershed can account for some of the variability in river water quality. As the proportion of disturbed land cover, such as mixed small-scale agriculture and bare land cover, increases, for example, so does the quantity of phosphorus in the River Njoro. Furthermore,

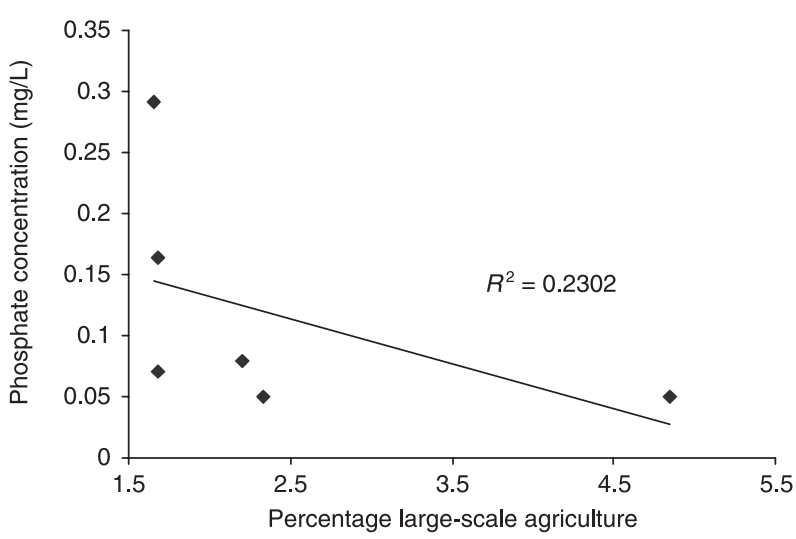

Fig. 8. Relationship between phosphate concentration and percentage proportion of land-cover areas of large-scale agriculture.

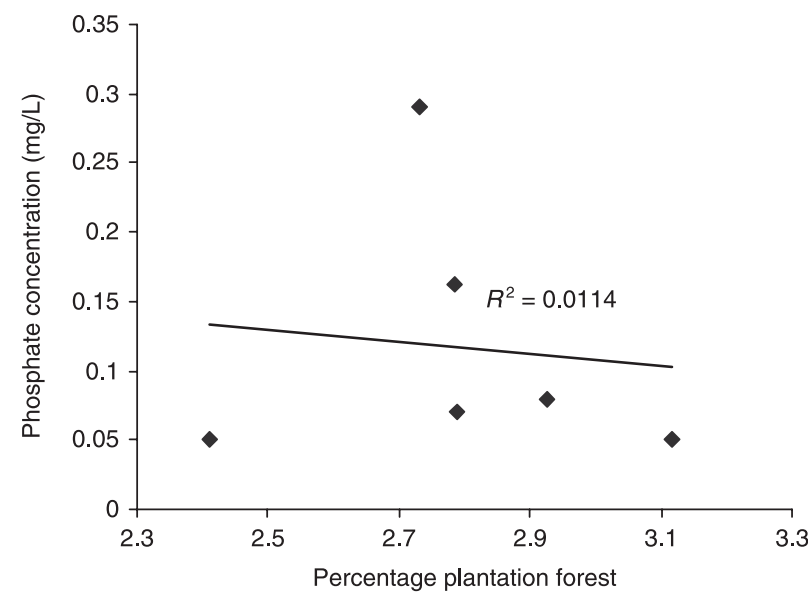

Fig. 9. Relationship between phosphate concentration and percentage proportion of land-cover areas of plantation forest. the larger the size of the subwatershed, the greater the quantity of phosphorus generated from it. Thus, landuse proportions are important for characterizing and modelling water quality in the watershed. Upland land uses are as important as near-stream land uses. The study demonstrates that large-scale agriculture, plantation forest, and indigenous forest cover reduce the phosphorus loss from the watershed. Riparian vegetation (forests, macrophytes) influences the channel form and stream function by contributing particulate organic matter and large woody debris; by providing shade; bank stability; sinks for organic matter; sediment; and by regulating nutrient movement and transformation.

\section{ACKNOWLEDGEMENTS}

We are grateful to the Global Livestock Collaborative Research Support Program of the US-AID for their support through the Sustainable Management of Watershed (SUMAWA), which facilitated the research work for this paper.

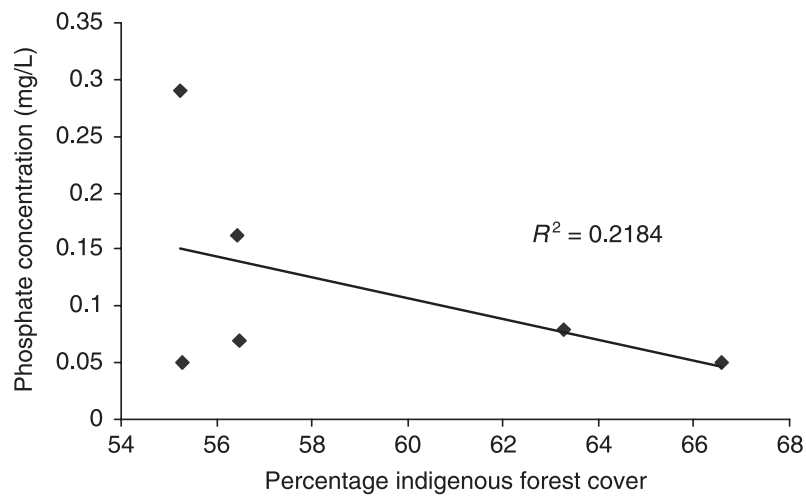

Fig. 10. Relationship between phosphate concentration and percentage proportion of land-cover areas of indigenous forest.

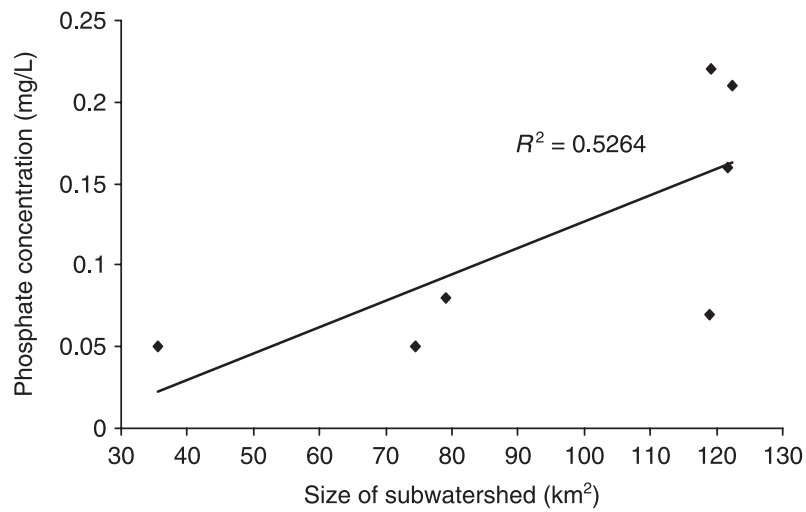

Fig. 11. Relationship between phosphate levels and size of subwatershed in River Njoro watershed. 


\section{REFERENCES}

American Public Health Association (1992) Standard Methods for the Examination of Water and Wastewater, 18th edn. American Public Health Association, Water Environment Federation and American Water Works Association, Washington, D.C.

Baldyga T. J., Miller S. N., Shivoga W. A. \& Maina-Gichaba C. (2004) Assessing the impact of land cover change in Kenya using remote sensing and hydrologic modeling. Proceedings of 2003 American Society for Photogrammetry and Remote Sensing Annual Conference, Denver, Colorado, USA, 23-28 May 2004.

Bretschko G. (1995) Report on the Tropical River Ecology Initiative, First Workshop (31 January-18 February 1994). Egerton University, Njoro, Kenya.

Chemilil M. (1995) The effect of human-induced watershed changes on streamflows. Doctoral Thesis, Loughborough University of Technology, Leicestershire, UK.

Garcia-Cabellos G., Byrne M., Stenberg M. et al. (2005) A small-scale constructed wetland to treat different types of wastewaters. In: Nutrient Management in Agricultural Watersheds: A Wetlands Solution (eds E. J. Dunne, K. R. Reddy \& O. T. Carton) pp. 224-229. Wageningen Academic Publishers, Wageningen, the Netherlands.

Government of Kenya (1974) Topographic Contour Maps sheet numbers - 118/2 Rongai, 118/4 Njoro, 119/1 Menengai, 119/3 Nakuru and 132/2 Mau Narok, all at a scale of $1: 50$ 000. Government of Kenya.

Harrington A. (2005) The relationship between plant vigour and ammonium concentrations in surface waters of constructed wetlands used to treat meat industry wastewaters in Ireland. In: Nutrient Management in
Agricultural Watersheds: A Wetlands Solution (eds E. J. Dunne, K. R. Reddy \& O. T. Carton) pp. 219-223. Wageningen Academic Publishers, Wageningen, the Netherlands.

Karanja A. K., China S. S. \& Kundu P. (1986) The influence of land use on Njoro River catchment between 1975 and 1985. Proceedings of the 3rd National Workshop on Soil and Water Conservation, Nairobi, Kenya, September, 1986, Department of Agricultural Engineering, University of Nairobi, and Swedish International Development Cooperation Agency.

Kenya Forest Working Group (2001). Excision and settlement in the Mau forest. Technical report, Kenya Forest Working Group, East African Wild Life Society, Nairobi, Kenya.

Lopez R. D. \& Nash M. S. (2006) Contribution of Nutrients and E. coli to Surface Water Condition in the Ozarks. Available from http://www.epa.gov/nerl/news/forum2006/ lopez.pdf.

Mathooko J. M. (2001) Disturbance of a Kenyan Rift valley stream by the daily activities of local people and their livestock. Hydrobiologia 458, 131-9.

Shivoga W. A. (2001) Influence of hydrology on the structure of invertebrate communities in two streams flowing into Lake Nakuru, Kenya. Hydrobiologia 458, 121-30.

SUMAWA. (2004). Sustainable Management of Watersheds Programme: The River Njoro, Kenya. Environmental Sciences Department, Egerton University, Njoro, Kenya.

Tiessen H. (ed) (1995) Phosphorus in the Global Environment: Transfers, Cycles and Management. Scientific Committee on Problems of the Environment (SCOPE 54), John Wiley \& Sons, New York. 480 pp. 